Marko N. Kitanović

Teaching Assistant University of Belgrade Faculty of Mechanical Engineering

Predrag D. Mrđa

Teaching Assistan University of Belgrade

Faculty of Mechanical Engineering

Slobodan J. Popović

Assistant Professor University of Belgrade

Faculty of Mechanical Engineering

Nenad L. Miljić

Assistant Professor University of Belgrade Faculty of Mechanical Engineering

\section{A Thermodynamic Work Cycle Simulation of a Syngas-Fueled Engine}

A syngas-fueled engine work cycle simulation has been conducted in the AVL BOOST environment in order to gain some insights into the expected engine performance and efficiency parameters. The study also provides the energy balance that will dictate the design of engine coolant and exhaust gas heat recuperation systems. A turbocharged six-cylinder gas engine serves as the basis on which the numerical studies have been conducted. A Vibe-based heat release model, customized to take into account the effect of excess-air ratio and ignition timing variations on the combustion duration and MFB curve shape is used to predict the heat release rate. A simple methodology for determining the total engine displacement for a given fuel production rate is also presented. The resulting brake mean effective pressure and efficiency parameters are lower than on a comparable natural gas-fueled engine but syngas is still an interesting alternative, particularly for cogeneration units.

Keywords: syngas, engine, simulation, Vibe, turbocharging.

\section{INTRODUCTION}

Nowadays, significant efforts are being invested in renewable energy sources research. One of the solutions in that regard is the exploitation of synthesis gas (syngas), a mixture containing carbon monoxide and hydrogen obtained from corn cob waste agricultural biomass. Indeed, this gas could be used in stationary cogeneration units to generate electricity and heat at very high combined efficiencies.

Syngas is a combustible gas produced by biomass gasification. Its exact composition depends upon the gasification process specifics, the biomass source and other parameters, but its combustible elements consist of a mixture of hydrogen and carbon monoxide. Due to hydrogen's very high laminar flame propagation speeds [1] and its broad ignition limits, syngas combustion can occur at low equivalence ratios (high excess-air ratios), which can be beneficial with regard to engine efficiency. Syngas, as other biomass-derived fuels, is considered carbon neutral; it is argued that the carbon dioxide release due to biofuel combustion is merely the release of quantities acquired during biomass growth, as opposed to burning fossil fuels, which releases 'new' quantities that were previously held in hydrocarbons during millions of years. Nevertheless, in order for renewable energies to make a significant breakthrough in the energy market, they must be economically viable and competitive, which translates to a requirement of having such characteristics that are presently in clear favor of fossil fuels (such as affordability, abundance, reliability, high energy density, etc.). The major barriers to an increased commercial viability of syngas in

Received: September 2016, Accepted: May 2017

Correspondence to: Marko N. Kitanović

Faculty of Mechanical Engineering,

Kraljice Marije 16, 11120 Belgrade 35, Serbia

E-mail: mkitanovic@mas.bg.ac.rs

doi:10.5937/fmet1704572K

(C) Faculty of Mechanical Engineering, Belgrade. All rights reserved particular are also related to certain requirements for reliable operation of internal combustion engines, namely: low tar and particulates concentrations, which raise some concerns with respect to the added complexity for syngas processing needs [2]. However, should these issues be solved at a relatively low cost, syngas could be used in a very efficient way to generate electricity and heating in cogeneration units.

The aim of this article is to present a methodology for a comprehensive numerical study of work cycle parameters of a syngas-fueled internal combustion engine and to highlight an approach to choosing the optimal solution relating to the choice of electric generator and the exhaust and coolant heat recuperation systems, based on the predicted performance and efficiency of the energy transformation process. The first part of the article will be dealing with the determination of the total engine displacement needed to accommodate the fuel production rate and a description of the engine simulation model, along with assumed parameter and values for the submodels used in the study, will be given. In the second part of the article, the results obtained from the simulation model will be presented and discussed. The final part of the article will be dealing with the conclusions.

\section{SIMULATION MODEL DESIGN}

In this part of the article, the simulation model used in the study will be described, along with its assumptions and parameters.

\subsection{Syngas fuel}

The syngas considered in this study is derived from corn cob biomass [3] and its composition is shown in Table 1. The lower heating value, gas constant, stoichiometric air-fuel ratio and nominal flow rates are presented in Table 2. Because the gasification process involves the 
use of air, a very high dilution of fuel by nitrogen is encountered, which has the detrimental effect of significantly reducing the energy density of the fuel.

Table 1. Syngas fuel composition

\begin{tabular}{|c|c|c|c|c|c|}
\hline \multicolumn{6}{|c|}{ Volumetric fractions (\%) } \\
\hline $\mathrm{N}_{2}$ & $\mathrm{H}_{2} \mathrm{O}$ & $\mathrm{CO}_{2}$ & $\mathrm{CO}$ & $\mathrm{H}_{2}$ & $\mathrm{CH}_{4}$ \\
\hline 43.71 & 9.5 & 8.6 & 24.16 & 12.22 & 1.81 \\
\hline
\end{tabular}

Table 2. Syngas fuel parameters

\begin{tabular}{|l|c|}
\hline Parameter & Value \\
\hline Lower heating value $[\mathrm{kJ} / \mathrm{kg}]$ & 4494.55 \\
\hline Stoichiometric AFR [-] & 1.2034 \\
\hline Fuel flow $[\mathrm{kg} / \mathrm{h}]$ & 398.7 \\
\hline
\end{tabular}

\subsection{Engine displacement calculation}

A preliminary numerical study is to be conducted to provide an early assessment with regards to the total engine displacement needed in order to fully use the syngas at its production rate (Table 1). For this purpose, the following equation, relating the total fresh charge mass flow rate through the engine to the engine displacement, volumetric efficiency, engine speed and fresh charge density has been used:

$$
\dot{m}=V_{\text {disp }} \cdot \eta_{V} \cdot \frac{2 n}{\tau} \cdot \frac{p_{I N T}}{R T_{I N T}}
$$

On the other hand, the total fresh charge mass flow through the engine can be expressed in the following manner:

$$
\dot{m}=\dot{m}_{A}+\dot{m}_{F}=\dot{m}_{F} \cdot(1+\lambda \cdot A F R s)
$$

By combining (1) and (2), one can arrive to a relation between the total engine displacement needed to accommodate the syngas-based fresh charge at its production rate and the pressure and temperature values of the fresh charge and the excess-air ratio. This relation, shown as a contour plot, is depicted in Figure 1.

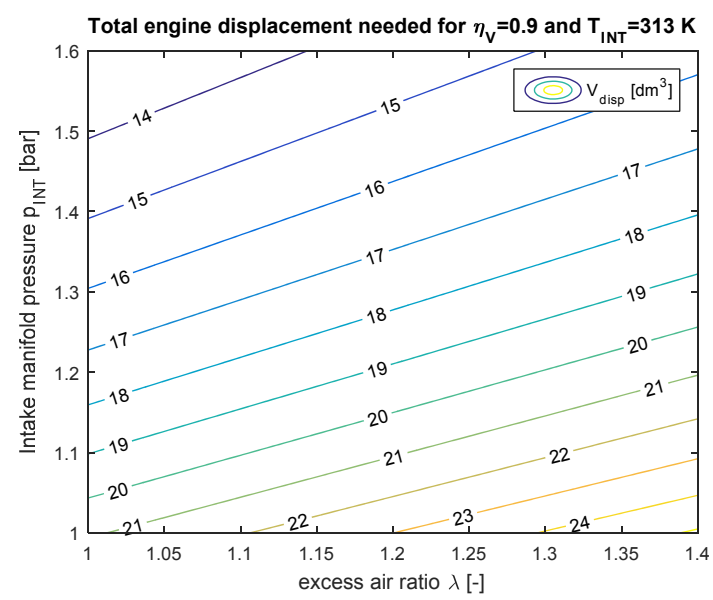

Figure 1. Total engine displacement needed for the syngas production rate

It can be concluded that depending on the state of the fresh charge (its excess-air ratio and density), the total engine displacement needed varies between 14 and
$24 \mathrm{dm}^{3}$. Bearing in mind that the engine simulated in this study is turbocharged and that excess-air ratios above 1.2 will not be considered, it has been decided that the range for the simulated engines displacement values will be from 14 to $18 \mathrm{dm}^{3}$.

The values for the engine geometry parameters (S/D and $\varepsilon$ ), as shown in Table 3, are derived from a Guascor SFGLD 180 syngas engine. The connecting rod ratio has been set to a value obtained from an AVL BOOST $11 \mathrm{dm}^{3}$ truck engine example model.

Table 3. Engine geometry parameters

\begin{tabular}{|l|c|}
\hline Parameter & Value \\
\hline Connecting rod ratio R/L [-] & 0.296 \\
\hline Stroke/bore ratio S/D [-] & 1.0855 \\
\hline Compression ratio $\varepsilon[-]$ & 9.3 \\
\hline
\end{tabular}

The actual values for the connecting rod length, the stroke and bore of the engine cylinders are calculated based on data in Table 3 and the actual engine displacement value used in the simulation.

\subsection{AVL BOOST engine model}

For the purpose of conducting this thermodynamic engine work cycle study, the AVL BOOST IC engine simulation software has been used. Its basis rests on implementing and solving the equation of the first law of thermodynamics for open systems in the engine cylinders and solving the $1 \mathrm{D}$ gas dynamics equations in the engine ducts and pipes (surrounding the engine cylinders).

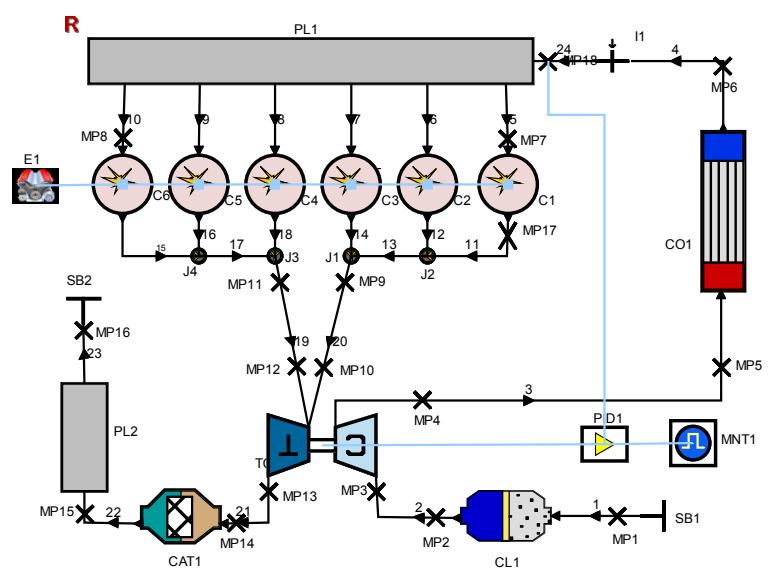

Figure 2. The AVL BOOST engine model

The AVL BOOST simulation model used for this study is shown in Figure 2. As can be seen, a 6-cylinder engine has been modeled along with a turbocharger and a PID controller to control the amount of fresh charge that flows into the intake manifold according to the syngas production rate and the corresponding excess-air ratio. This controller also serves to vary the turbine size so that the intake manifold density reaches the levels needed to attain the desired fresh charge flow for different engine displacement configurations. This has allowed us to evaluate the impact of engine displacement on the engine gas exchange process and its corresponding effects on the high-pressure cycle and engine operating parameters. A simplified, "mapless" 
turbocharger model has been used in the "Turbine Layout Calculation" mode, in which the target boost pressure is attained by intervening on the effective flow area of the turbine. In this case, the entire exhaust mass flow goes through the turbine impeller and thus decreases the turbine pressure ratio needed for a given target boost pressure compared to a turbocharger model with a wastegate (WG).

The engine model also incorporates a charge-air cooler (CAC) to significantly raise the charge density and lower the compressor pressure ratio values needed for a given engine fresh charge flow. In this study, the charge-air cooler effectiveness has been set to $75 \%$ and the coolant temperature to $298 \mathrm{~K}$.

For modeling the heat transfer processes in the cylinders, a revised Woschni model [4] has been used to evaluate the heat transfer coefficient between the gas and the cylinder walls.

In order to properly predict the temperature and, consequently, the pressure of the charge in the cylinders, a model for the heat capacities at constant pressure of the fuel, burned gases and air is necessary. For this purpose, the AVL BOOST Gas Properties Tool has been used for generating the dependencies of specific heat, enthalpy and entropy of the fuel on gas temperature.

For modeling the combustion process, a Vibe-based heat release law has been implemented in the model. The fraction of the fuel mass burned during combustion is given by the following equation [5]:

$$
x=1-\exp \left(-a \cdot\left(\frac{\alpha-S O C}{B D U R}\right)^{m+1}\right)
$$

where $a$ is a Vibe parameter defining the end of combustion and is equal to 6.908 for complete combustion. The $S O C$ and $B D U R$ are the Start Of Combustion and Burn DURation parameters expressed in crank angle degrees (CAD), respectively. The variable $m$ is the Vibe shape parameter and represents the position of the brunt of the combustion. The actual crankshaft angle during combustion is denoted by $\alpha$.

\subsection{Vibe combustion model correlations}

In order to take into consideration the effect of the excess-air ratio on the heat-release rate, a Vibe correlation for a biogas-fueled engine, obtained by Carrera et al. $[6,7]$ has been used. It quantifies the Vibe $B D U R, a$ and $m$ parameters as functions of the compression ratio, engine speed, excess-air ratio, Start of Combustion angle and the $\mathrm{CO}_{2}$ volumetric fraction in the fuel as follows:

$$
\begin{aligned}
& \begin{array}{l}
\text { BDUR }=42.0-6.625 \cdot x_{1}+6.25 \cdot x_{2} \\
\quad+15.375 \cdot x_{3}+4.0625 \cdot x_{4}+0.0625 \cdot x_{5}
\end{array} \\
& \begin{array}{l}
a= \\
\quad 6.76+0.144 \cdot x_{1}-0.813 \cdot x_{2}-2.167 \cdot x_{3} \\
-1.078 \cdot x_{4}-0.0091 \cdot x_{5}
\end{array} \\
& m=1.675+0.368 \cdot x_{1}-0.25 \cdot x_{2}-0.8321 \cdot x_{3} \\
& \quad-0.75 \cdot x_{4}+0.025 \cdot x_{5}
\end{aligned}
$$

The $x_{i}$ variables are calculated as follows:

$$
\begin{gathered}
x_{1}=\frac{\varepsilon}{2.8}-4 \\
x_{2}=0.001 \cdot n-2 \\
x_{3}=4 \cdot \lambda-5 \\
x_{4}=0.05 \cdot S O C+1 \\
x_{5}=0.05 \cdot r_{\mathrm{CO}_{2}}-1
\end{gathered}
$$

Since the engine used in this simulation is a stationary, electrical energy-generating unit that is intended to run at only one engine speed (1500 RPM), the actual number of independent variables is only two in our case (the excess-air ratio and spark timing).

The previously described model has been modified by offsetting the values of the BDUR and Vibe shape parameters so as to achieve burn duration of $50 \mathrm{CAD}$, the Vibe shape parameter value of 2.5 at the spark timing of 18 CAD BTDC at the stoichiometric AFR. Since only stoichiometric and lean burn combustion are considered, the $a$ parameter is held at a constant value of 6.908. The resulting values for the combustion duration, Vibe shape and spark timing parameters are shown in Table 4. It should also be noted that the spark timing has been chosen in accordance with the condition of achieving the point of $50 \% \mathrm{MFB}$ at $10 \mathrm{CAD}$ ATDC.

Table 4. Vibe heat release parameters used in the simulation

\begin{tabular}{|l|c|c|c|c|c|}
\hline Excess-air ratio* & 1 & 1.05 & 1.1 & 1.15 & 1.2 \\
\hline Burn duration [CAD] & 50 & 52.9 & 55.9 & 58.8 & 61.9 \\
\hline Shape parameter [-] & 2.5 & 2.36 & 2.22 & 2.07 & 1.91 \\
\hline $\begin{array}{l}\text { Spark timing [CAD } \\
\text { BTDC] }\end{array}$ & 16 & 16.7 & 17.3 & 17.8 & 18.1 \\
\hline
\end{tabular}

*Setpoint values; actual excess-air ratios achieved differ by less than $0.6 \%$

\section{SIMULATION RESULTS}

The results of the BOOST simulation are presented in this section. 15 simulation runs have been conducted with two independent variables: the excess-air ratio (5 values) and the total engine displacement (3 different values). All runs have been carried out at the engine speed of 1500 RPM. In order to calculate the brake engine parameters from the indicated, a constant value for the friction mean effective pressure (FMEP) of 1.366 bar has been assumed. This value has been obtained by interpolating a linear (engine speeddependent) FMEP model of an $11 \mathrm{dm}^{3}$ truck engine example model in AVL BOOST.

The indicated cylinder pressure curves for the stoichiometric air-fuel ratio are shown in Figure 3 and 4 as functions of the crankshaft angle and cylinder volume, respectively. The maximum cylinder pressure of 59.4 bar is achieved at the excess-air ratio of 1.2 for the smallest engine displacement, which can be explained by the fact that the largest fresh charge mass flow runs through the engine with the smallest displacement. 


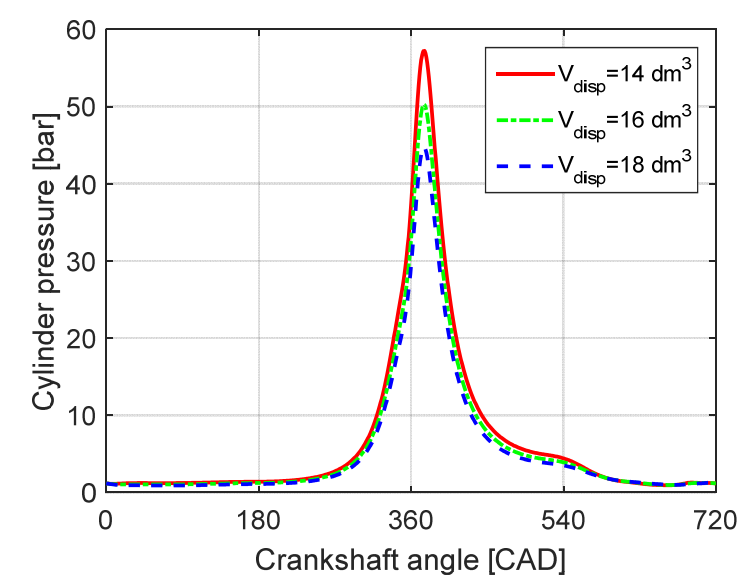

Figure 3. Indicated cylinder pressure shown as function of the crankshaft angle at the stoichiometric AFR

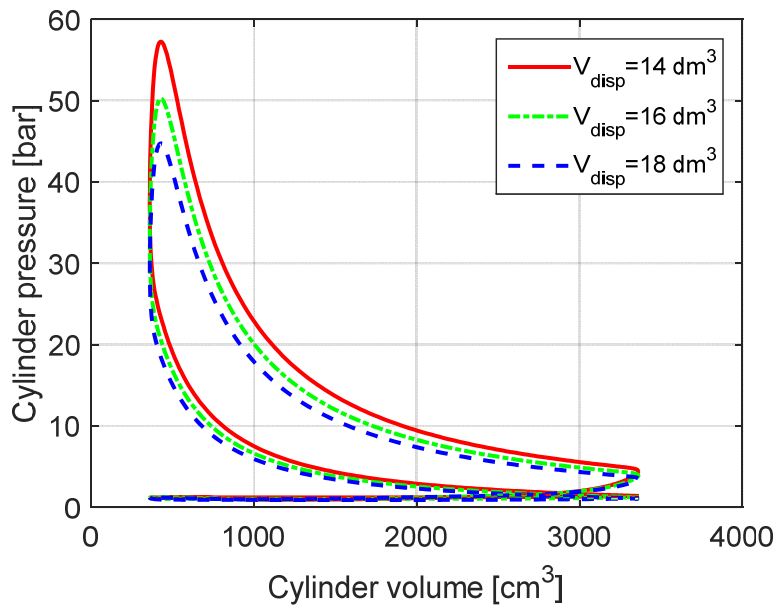

Figure 4. Indicated cylinder pressure shown as function of the cylinder volume at the stoichiometric AFR

By reducing the engine displacement while keeping the same given fuel mass flow, the specific work of the compressor must be raised, hence contributing to the elevated in-cylinder pressure. This is why the boost pressure rises significantly with the reduction of the engine displacement (Figure 5).

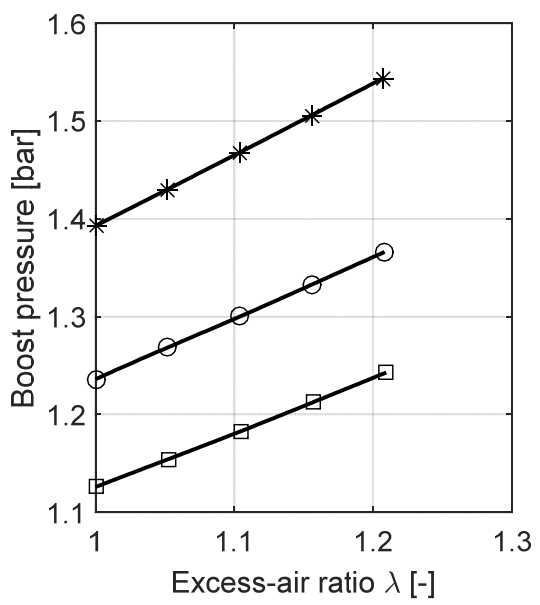

$$
\begin{aligned}
& * \mathrm{~V}_{\text {disp }}=14 \mathrm{dm}^{3} \\
& \mathrm{~V}_{\text {disp }}=16 \mathrm{dm}^{3} \\
& \square \quad \mathrm{V}_{\text {disp }}=18 \mathrm{dm}^{3}
\end{aligned}
$$

Figure 5. The variation of the boost pressure with respect to the excess-air ratio and the engine displacement

The intake manifold temperature rises only by a couple of degrees due to the assumption of constant turbocharger efficiency $(70 \%)$ and the fact that an intercooler is used. These results are shown in Figure 6.

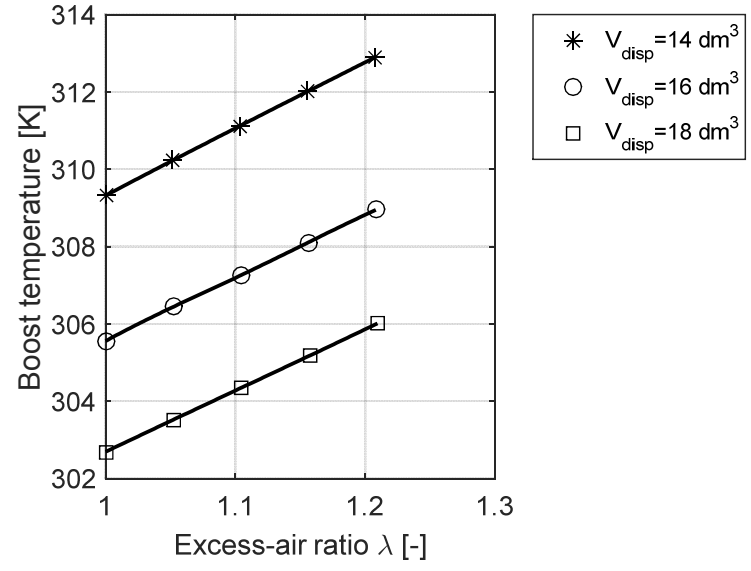

Figure 6. The variation of the intake manifold temperature with respect to the excess-air ratio and the engine displacement

The resulting Indicated Mean Effective Pressure (IMEP) of the gas-exchange process is shown in Figure 7. By increasing the total fresh charge mass flow (by keeping the same fuel mass flow and increasing the air mass flow by raising the excess-air ratio), the negative effect of the gas-exchange process on the indicated work diminishes, with the largest effect seen on the smallest engine. By increasing the excess-air ratio for a given engine displacement, the stagnation temperature of the burned charge at the turbine entry decreases but the stagnation pressure and the mass flow increase, thus giving a disproportionate increase in the boost pressure compared to the increase in the pressure upstream of the turbine.

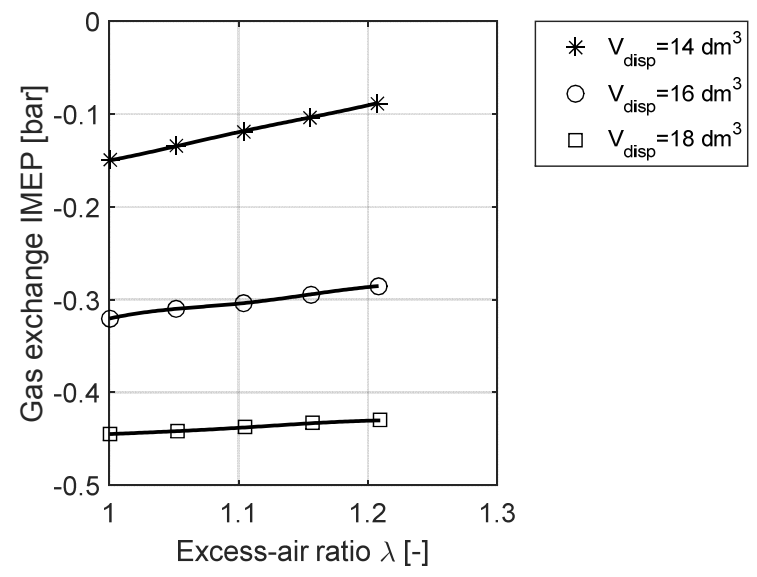

Figure 7. The variation of the gas exchange IMEP with respect to the excess-air ratio and the engine displacement

The engine brake power curves are shown in Figure 8. Even though the combustion duration increases, the maximum cylinder pressure and temperature increase (while the fresh charge specific heat decreases) with higher excess-air ratio values. This leads to an increase in the indicated efficiency, resulting in higher brake engine power values. These range from 146 to $168 \mathrm{~kW}$, giving Brake Mean Effective Pressure (BMEP) values varying from 6.48 to 9.62 bar. The BMEP values are significantly lower than on a natural gas generator sets of comparable power, primarily due to the significantly lower fresh charge mass-corrected heating value of syngas. 


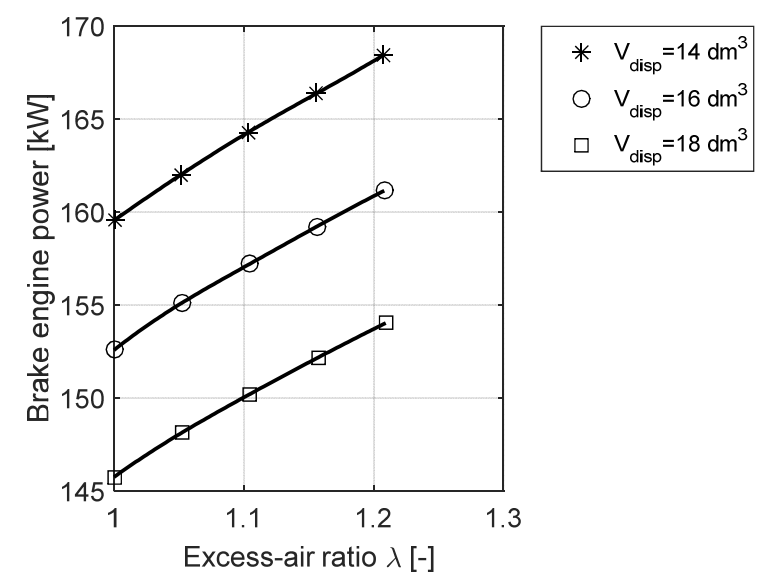

Figure 8. The variation of the brake engine power with respect to the excess-air ratio and the engine displacement

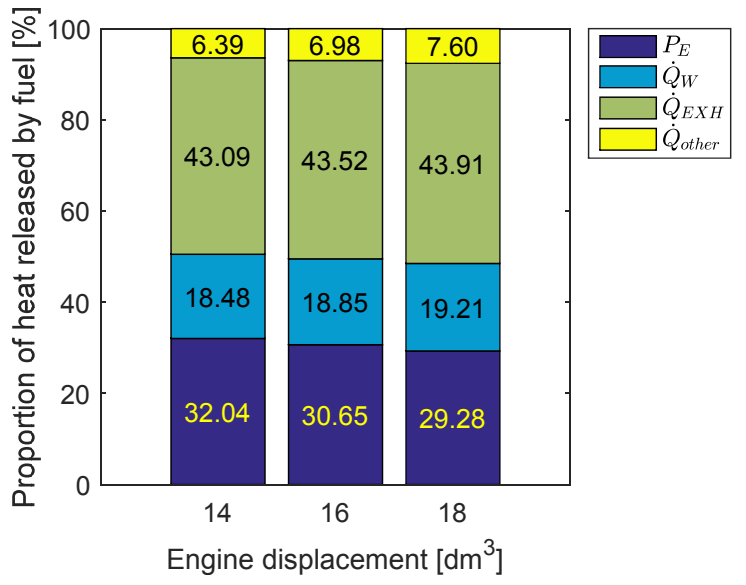

Figure 9. The energy balance at stoichiometric AFR

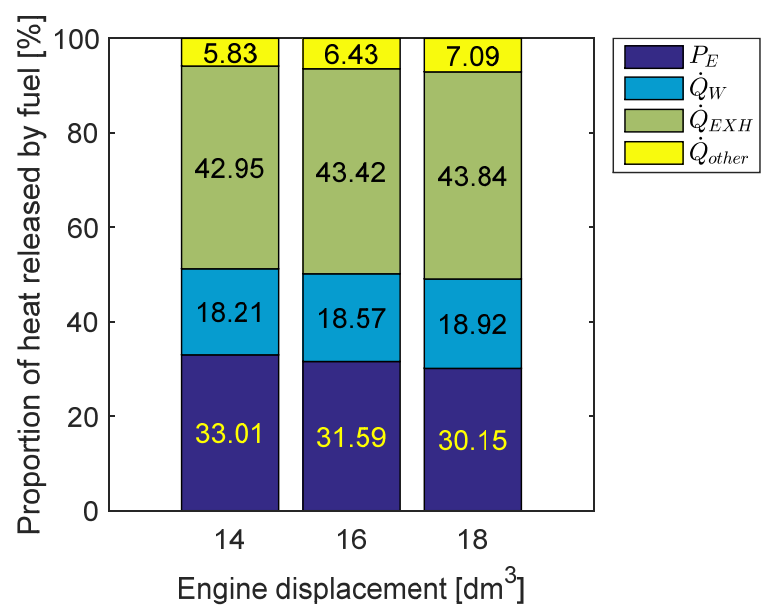

Figure 10. The energy balance at the excess-air ratio of 1.1

For evaluating the expected cogeneration performance potentials of the syngas-fueled engine, the energy balance parameters have been extracted from the BOOST simulation and are shown in Figures 9, 10 and 11. The total heat released by the fuel equals $497.8 \mathrm{~kW}$ (Table 2). About a third of this energy is converted to mechanical energy at the crankshaft. Indeed, the lowest brake efficiency of $29.28 \%$ is achieved for the biggest engine at stoichiometric AFR and the highest efficiency of $33.84 \%$ is reached for the smallest engine at the leanest air-fuel ratio.

On the other hand, the waste heat rise with increasing displacement and fuel enrichment. An exhaust energy recuperation device could harness a considerable amount of energy released during combustion, with potentials ranging from $42.92 \%$ to $43.91 \%$ (or 213.6 to $218.6 \mathrm{~kW}$ in absolute terms). A lower, but nonetheless significant amount of fuel energy is available for an engine cooling heat recuperation system, with fractions ranging from $17.97 \%$ to $19.21 \%$ ( 89.5 to $95.6 \mathrm{~kW}$ in absolute terms).

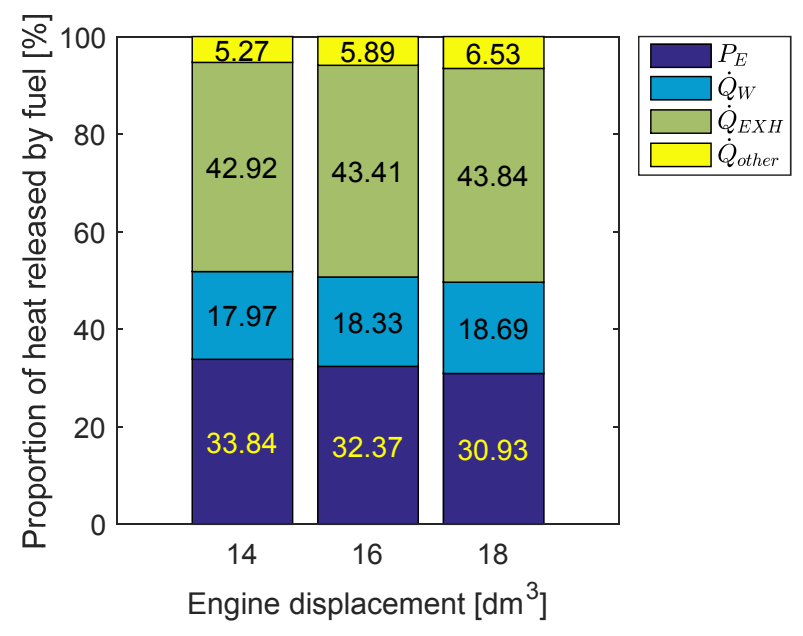

Figure 11. The energy balance at the excess-air ratio of 1.2

\section{CONCLUSION}

A thermodynamic work cycle simulation has been conducted in order to assess the expected performance and efficiency of a syngas-fueled engine. The best brake power and efficiency values are obtained for the smallest engine $\left(14 \mathrm{dm}^{3}\right)$ and the leanest fuel mixture $(\lambda=1.2)$, for which the boost pressure is the highest. However, it should be noted that this operating point might be situated beyond the knock limit. Compared to natural gas-fueled engines, the brake power and efficiency are lower, primarily due to comparatively lower values of the fresh charge mass-corrected LHV and the compression ratio.

The stoichiometric fresh charge mass-corrected LHV for syngas is approximately $25 \%$ lower than for natural gas. Even though the gas constant of the natural gas fuel is $32 \%$ higher than that of syngas considered in this study, when accounting for the respective stoichiometric AFR, the gas constant of a syngas fresh charge is $3 \%$ higher than that of natural gas. This causes the density of the fresh charge at standard conditions to be $3 \%$ lower and, combined with the difference in LHV of the fuels, leads to a reduction in volumetric LHV (at standard atmospheric conditions) of $27 \%$, partially explaining the low BMEP and brake power values.

Another disadvantage of syngas in engine applications is the restriction placed on the maximum compression ratio values allowable to avoid abnormal combustion conditions, which are significantly lower than on comparable natural gas engines. This further explains the low brake efficiency achieved in this numerical study. Nonetheless, syngas can be an interesting alternative to fossil fuels in cases where the costs associated with the production and preparation of the former are low compared to the latter. 
With regard to the simulation model presented in this study, future efforts should be focused on implementing a phenomenological combustion model coupled with a detonation submodel in order to predict the knock limits of the engine.

\section{REFERENCES}

[1] Hagos, F. Y., Aziz, A. R. A., \& Sulaiman, S. A.: Syngas $(\mathrm{H} 2 / \mathrm{CO})$ in a spark-ignition direct-injection engine. Part 1: Combustion, performance and emissions comparison with $\mathrm{CNG}$, International Journal of Hydrogen Energy, Vol. 39, No. 31, pp. 17884-17895, 2014.

[2] Yan, J., Shamim, T., Chou, S.K., Li, H., De Filippis, P., Scarsella, M., de Caprariis, B., Uccellari, R.: Biomass Gasification Plant and Syngas Clean-up System, in: Clean, Efficient and Affordable Energy for a Sustainable Future: The 7th International Conference on Applied Energy (ICAE2015), Energy Procedia, Volume 75, 2015, pp. 240-245.

[3] Jankes, G., Trninić, M., Stamenić, M., Simonović, T., Tanasić, N., Labus, J.: Biomass gasification with CHP production: A review of state of the art technology and near future perspectives, Thermal Science, Vol. 16, Issue suppl. 1, pp. 115-130, 2012.

[4] Woschni, G., Einfluss von Russablagerungen auf den Waermeuebergang zwischen Arbeitsgas und Wand im Dieselmotor, in: proceedings to $\mathrm{Der}$ Arbeitsprozess des Verbrennungsmotors, Graz 1991.

[5] Lindström, F., Ångström, H., Kalghatgi, G. and Möller, C.: An Empirical SI Combustion Model Using Laminar Burning Velocity Correlations, SAE Technical Paper 2005-01-2106, 2005.

[6] Carrera-Escobedo, J.L. et al.: Modelo termodinámico de una zona con relaciones para el proceso de combustión en motores alimentados con biogas, Revista mexicana de ingeniería química, Vol. 12, No. 3, pp. 649-660, 2013.

[7] Carrera, J. L., Riesco, J., Martinez, S. M., Sanchez, F. A., \& Gallegos, A. M.: NUMERICAL STUDY ON THE COMBUSTION PROCESS OF A BIOGAS SPARK IGNITION ENGINE, Thermal Science, Vol. 17, No. 1, 2013.

\section{NOMENCLATURE}

a Vibe completeness of combustion constant

$A F R \quad$ Air to fuel ratio

AFRs Stoichiometric air to fuel ratio

$B D U R \quad$ Heat release duration

$B M E P$ Brake Mean Effective Pressure

FMEP Friction Mean Effective Pressure

$I M E P \quad$ Indicated Mean Effective Pressure

$L H V \quad$ Lower heating value

$m \quad$ Vibe shape parameter

$\dot{m} \quad$ Fresh charge mass flow rate

$\begin{array}{ll}\dot{m}_{A} & \text { Air mass flow rate } \\ \dot{m}_{F} & \text { Fuel mass flow rate } \\ M F B & \text { Mass fraction burned } \\ n & \text { Engine speed } \\ \dot{P}_{e} & \text { Brake engine power } \\ p_{I N T} & \text { Intake manifold pressure } \\ \dot{Q}_{E X H} & \text { Exhaust gas heat flux } \\ \dot{Q}_{\text {other }} & \text { Convective and radiative heat fluxes } \\ \dot{Q}_{W} & \text { In-cylinder heat transfer flux } \\ R & \text { Gas constant } \\ S O C & \text { Start of combustion angle } \\ T_{I N T} & \text { Intake manifold temperature } \\ V_{d i s p} & \text { Engine displacement } \\ x & \text { Fraction of the fuel mass burned during } \\ & \text { combustion }\end{array}$

\section{Greek symbols}

$\alpha \quad$ Crankshaft angle

$\varepsilon \quad$ Compression ratio

$\eta_{V} \quad$ Volumetric efficiency

$\lambda \quad$ Excess-air ratio

$\tau \quad$ Number of strokes per cycle

\section{СИМУЛАЦИЈА РАДНОГ ПРОЦЕСА МОТОРА ПОГОЊЕНОГ СИНТЕЗНИМ ГАСОМ}

\section{М. Китановић, П. Мрђа, С. Поповић, Н. Миљић}

Спроведена је симулација радног процеса мотора СУС који користи синтезни гас као гориво у симулационом окружењу AVL BOOST. Циљ симулације је стицање увида у очекиване радне параметре мотора. Студија такође даје увид у топлотни биланс мотора који омогућава димензионисање уређаја за рекуперацију отпадних топлота у когенеративном погону. Један турбопуњени, 6-цилиндарски гасни мотор чини основу над којом је спроведена нумеричка студија. За моделовање процеса ослобађања топлоте коришћен је Вибеов модел са корелационим параметрима који узимају у обзир утицај састава смеше и угла претпаљења на укупно трајање сагоревања и облик диференцијалног тока ослобађања топлоте.

У раду је дата и једноставна методологија за утврђивање потребне радне запремине мотора за дати проток синтезног гаса. Добијене вредности средњег ефективног притиска као и степена корисности мотора су значајно мање у поређењу са моторима који користе природни гас, али употреба синтезног гаса може представљати занимљиву алтернативу, нарочито у случају коришћења когенеративног постројења. 